\title{
Circular Antisense Oligonucleotides Inhibit Growth of Chronic Myeloid Leukemia Cells
}

\author{
Peter T. Rowley, ${ }^{1}$ Barbara A. Kosciolek, ${ }^{1}$ and Eric T. Kool ${ }^{2}$ \\ ${ }^{1}$ Department of Medicine and Division of Genetics and ${ }^{2}$ Department \\ of Chemistry, University of Rochester, Rochester, New York, U.S.A.
}

Accepted August 18, 1999.

\begin{abstract}
Background: Antisense represents a conceptually powerful method for regulating gene expression. However, antisense oligonucleotides developed to date manifest two serious limitations-nuclease susceptibility and nonspecific hybridization. Circular oligonucleotides may be superior to conventional linear oligonucleotides in both respects. First, circular agents, having no ends, are exonuclease-resistant. Second, they bind to complementary strands of RNA and DNA with a higher affinity than corresponding linear agents.

Methods and Results: We assessed the activity of circular phosphodiester deoxynucleotides using chronic myeloid cell lines by targeting polypurine sequences. To represent cells having a $b c r 3 / a b l 2-t y p e$ junction, we used K562 cells. A circle targeting a $b c r$ polypurine sequence 385 nucleotides $5^{\prime}$ to the junction decreased the cell number by day 5 with an $\mathrm{IC}_{50}$ of $9 \mu \mathrm{M}$. To represent cells
\end{abstract}

having a bcr2/abl2-type junction, we used BV173 cells. A circle targeting the $b c r-a b l$ junction itself decreased the cell number by day 7 with an $\mathrm{IC}_{50}$ of $8 \mu \mathrm{M}$. Control oligonucleotides, whether the same sequence uncircularized or circles with the same nucleotide composition but in scrambled sequence, had little effect. Unlike linear agents, circles were stable when incubated in $10 \%$ serum. The amount of bcr-abl protein detected by Western blotting using a specific anti-bcr-abl antibody at $24 \mathrm{hr}$ in antisense-treated BV173 cells was only $10 \%$ of that of cells treated with control circles, which demonstrates an antisense mechanism of action.

Conclusions: Circular oligodeoxyribonucleotides ( 1 ) inhibit the accumulation of CML cells, (2) decrease the amount of bcr-abl protein per cell, (3) have sequenceselective activity, and (4) are more active than linear oligonucleotides containing only the base-pairing region.

\section{Introduction}

Energizing the drive to discover the molecular basis of malignant disease has been the conviction that understanding its molecular basis will lead to effective and specific therapeutic agents. The antisense approach targets a nucleotide sequence by the use of an oligonucleotide of complementary sequence. There are two theoretical advantages to targeting the gene's messenger RNA rather than targeting the gene's protein product. One is that there are fewer messenger

Address correspondence and reprint requests to Dr. Peter T. Rowley, Division of Genetics, Box 641, University of Rochester, Rochester, NY 14642, U.S.A. Phone: 716-175-3461; Fax: 716-273-1034; E-mail:

peter_rowley@urmc.rochester.edu molecules than protein product molecules. A second is that the structure of the mutation dictates the structure of an agent that can specifically bind it, i.e., the complementary nucleotide sequence.

Chronic myeloid leukemia is a good model for examining the promise of antisense therapy. The primary lesion in most cases, a reciprocal translocation between the ends of the long arms of chromosomes 9 and 22, is well characterized (1). The result is the formation of a hybrid gene on the translocated chromosome 22, bcr-abl. This hybrid gene consists of a $5^{\prime}$-portion from the $b c r$ gene on chromosome 22 , and a 3 '-portion from the $a b l$ gene translocated from chromosome 9. The junction of $b c r$ and $a b l$ thus constitutes a sequence unique to the leukemic cell population. 
An antisense agent that could prevent the multiplication of cells with the hybrid sequence, but spare cells without this sequence, would have the specificity desired in a chemotherapeutic agent.

The antisense approach can be investigated either by gene transfer with the consequent production of an antisense RNA or by the administration of oligonucleotides. The latter approach has been the one generally adopted because it is simpler and permits convenient testing of a large variety of agents. Oligonucleotides of DNA, rather than of RNA, are generally used because of the former's greater stability in biological fluids. Early reports that $b c r-a b l$ antisense oligonucleotides caused sequence-specific inhibition of the growth of cytomegalovirus (CML) cell lines

(2) or of colonies from CML marrow progenitors

(3) aroused great interest.

We found that an antisense phosphodiester oligonucleotide directed to the $b c r-a b l$ junction had no antiproliferative effect on CML cell lines (4). We suspected that it was promptly degraded by nucleases, either in the serum or within the cell. We also tested phosphorothioates, i.e., oligomers in which an oxygen in the naturally occurring phosphodiester linkage is replaced by sulphur to make the linkage relatively nucleaseresistant. This antisense agent was inhibitory, but the effect was not sequence-specific.

The activity principally responsible for the intracellular degradation of oligonucleotides is a 3 '-exonuclease (5). Therefore, we first tried protecting phosphodiester oligonucleotides by capping the ends. We replaced the 5'-hydroxyl group with a dimethoxytrityl group, and the $3^{\prime}$ hydroxyl group with a 3'-amino, 2-hydroxypropyl group. These agents did have a sequencespecific effect $(4,6)$, confirming the idea that the unmodified phosphodiesters were ineffective because of exonuclease degradation. However, the inhibitory effect on proliferation was only modest. Increasing oligonucleotide concentration reduced cell concentration in a sequence-nonspecific manner.

Other investigators have also had mixed results. Some have found sequence nonspecificity (7-9) or at least nonspecificity for the specific breakpoint $(10,11)$. Many studies used phosphorothioates that can have nonspecific effects. Some investigators claim the mechanism is other than an antisense one, i.e., a sequence-dependent mechanism unrelated to the $b c r-a b l$ sequence $(12,13)$. Others have found no effect on the bcr-abl protein level (14) or direct inhibition of the bcr-abl-associated protein-tyrosine kinase activity $(15,16)$. Problems encountered with antisense inhibition of bcr-abl have been reviewed (17).

We reasoned that, since capped phosphodiesters had shown some promise (4), an ideal antisense agent might have phosphodiester linkages but lack ends, i.e., be a circular phosphodiester. Such a structure confers two advantages. The first is complete resistance to exonuclease activity, and the second is that such circles have the potential to bind much more tightly than linear structures because the cyclic structure limits conformational freedom $(18,19)$.

\section{Materials and Methods}

Cells

K562 cells (20) were obtained from the American Type Culture Collection (Rockville, MD). BV173 cells (21) were generously provided by Dr. Bruno Calabretta of Thomas Jefferson University. Each group was maintained by dilution three times weekly in RPMI 1640-10\% heatinactivated $\left(65^{\circ} \mathrm{C}, 30 \mathrm{~min}\right)$ fetal bovine serum (FBS).

\section{Culture}

Cells were first preincubated in RPMI 1640 (Gibco BRL, Grand Island, NY) at the stated oligonucleotide concentration without serum. After 4 $\mathrm{hr}$, heat-treated FBS was added to a final concentration of $10 \%$ and oligonucleotide was again added to the same final concentration. Cell concentration was determined by a hemocytometer. Cell counts represent viable cells determined by trypan blue exclusion.

\section{Oligonucleotide Synthesis}

Oligodeoxynucleotides were synthesized on a Pharmacia LKB (Piscataway, NJ) or Applied Biosystems 392 (Foster City, CA) instrument using standard phosphoramidite chemistry (22). $\beta$-Cyanoethyl phosphoramidite monomers were obtained from Cruachem (Dulles, VA) or Applied Biosystems. Phosphorylation on the $5^{\prime}$-ends of oligomers was carried out with (2-cyanoethoxy)-2-(2'-O-4,4'-dimethoxytrityloxyethylsulfonyl)ethoxy- $N, N$-diisopropylaminophosphine (23), also purchased from Cruachem. Oligomers were purified by electrophoresis on $20 \%$ acrylamide gels in $8 \mathrm{M}$ urea 


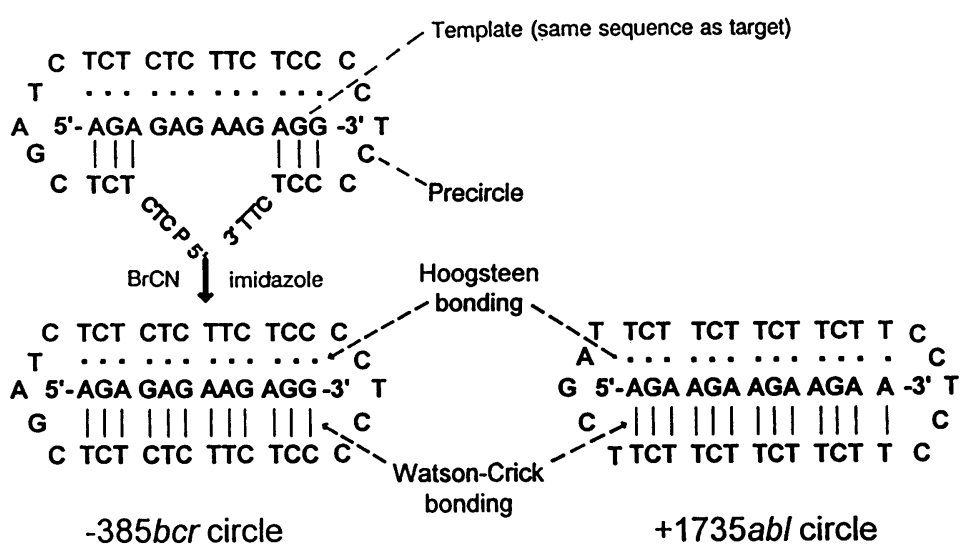

Fig. 1. Structure of circular deoxynucleotides targeting $\mathrm{K} 562$ cell $b c r-a b l$ mRNA 385 nucleotides $5^{\prime}$ and 1735 nucleotides $3^{\prime}$ from the $b c r-a b l$ junction. Shown also is the method of synthesis of the former, including the target-like template oligonucleotide used to approximate the ends of the linear precursor. and Tris-borate-EDTA buffer (24). The DNA was isolated from the gels by excision, followed by elution and dialysis, and was quantitated by absorbance at $260 \mathrm{~nm}$ using extinction coefficients that were calculated by the nearest neighbor method (25).

Linear 5'-phosphorylated circle precursors were synthesized and then hybridized with short complementary DNA templates (Fig. 1). These precircle complexes bring the reactive 3 '-hydroxyl and $5^{\prime}$-phosphate ends adjacent to one another, and these ends are ligated using aqueous $\mathrm{BrCN} / \mathrm{imidazole} / \mathrm{Ni}^{2+}(26-28)$. In all cases in this study, the precircle ends were joined at the center position of a Watson-Crick binding domain. We have found that this approach gives higher yields than does ligation within the Hoogsteen domain, although the products are identical. Isolation of the circular product (the principal new product from the reaction) was carried out by gel electrophoresis. The circular products typically migrate on a gel at $\sim 0.9$ times the rate of their linear precursors. Circularity was confirmed by resistance to $3^{\prime}$-exonuclease cleavage and by the decrease in electrophoretic mobility upon endonuclease cleavage characteristic of conversion of a circular to a linear structure. An alternative strategy for synthesizing circular oligonucleotides that provides a higher yield, involving one-step circularization from two halflength oligomers (29), was used for some preparations. Staining of oligonucleotides in gels was done with Stains-All (Sigma, St. Louis, MO).

\section{Immunoblotting}

BV173 cells $\left(3 \times 10^{5}\right)$ were lysed by vortexing with an equal volume of $2 \times$ Laemmli sample buffer (4\% SDS, $15 \%$ glycerol, $0.1 \% \beta$-mercap- toethanol, $125 \mathrm{mM}$ Tris- $\mathrm{Cl}, \mathrm{pH} 6.8$, and $0.002 \%$ bromophenol blue). Samples were heated to $95^{\circ} \mathrm{C}$ for $90 \mathrm{sec}$, vortexed, and reheated at $95^{\circ} \mathrm{C}$ for $90 \mathrm{sec}$. Entire samples $(70 \mu \mathrm{l})$ were applied to $7 \%$ resolving, $5 \%$ stacking, SDS polyacrylamide gels $(1.5 \mathrm{~mm} \times 14 \mathrm{~cm} \times 16 \mathrm{~cm})$. Gels were electrophoresed for $30 \mathrm{~min}$ at $120 \mathrm{~V}$ followed by $54 \mathrm{~V}$ for $17.5 \mathrm{hr}$. Proteins were transferred onto Optitran (Schleicher \& Schuell, Keene, $\mathrm{NH}$ ) in a solution of $0.025 \mathrm{M}$ Tris, $0.192 \mathrm{M}$ glycine, $10 \%$ methanol, and $0.1 \%$ SDS at $4^{\circ} \mathrm{C}$ for $2 \mathrm{hr}$ at $24 \mathrm{~V}$ using the IDEA Scientific transfer apparatus (Corvallis, OR). Membranes were air dried before immunodetection.

For immunodetection the Western Blot Kit from Kirkegaard \& Perry Laboratories (Gaithersburg, MD) was used. The membrane was incubated for $2 \mathrm{hr}$ at room temperature in blocking solution. The membrane was then incubated at room temperature for $2 \mathrm{hr}$ in anti-abl pEX5 monoclonal antibody (30) (a generous gift of Dr. Charles Sawyer, UCLA) (1:4000) with rapid agitation. Antibody solution was removed and the membrane was washed for $8 \mathrm{~min}$ in wash buffer with mild agitation. Washing was repeated two times. The membrane was then incubated with horseradish peroxidase-conjugated goat antimouse IgG $(1: 10,000)$ for $1 \mathrm{hr}$ at room temperature with rapid agitation and washed again as above. Chemiluminescence was detected immediately as described by the manufacturer. Film exposure was for $30 \mathrm{~min}$.

\section{Results}

There are two types of hybrid message resulting from the two common types of translocation breakpoints. Each type of junction involves exon 


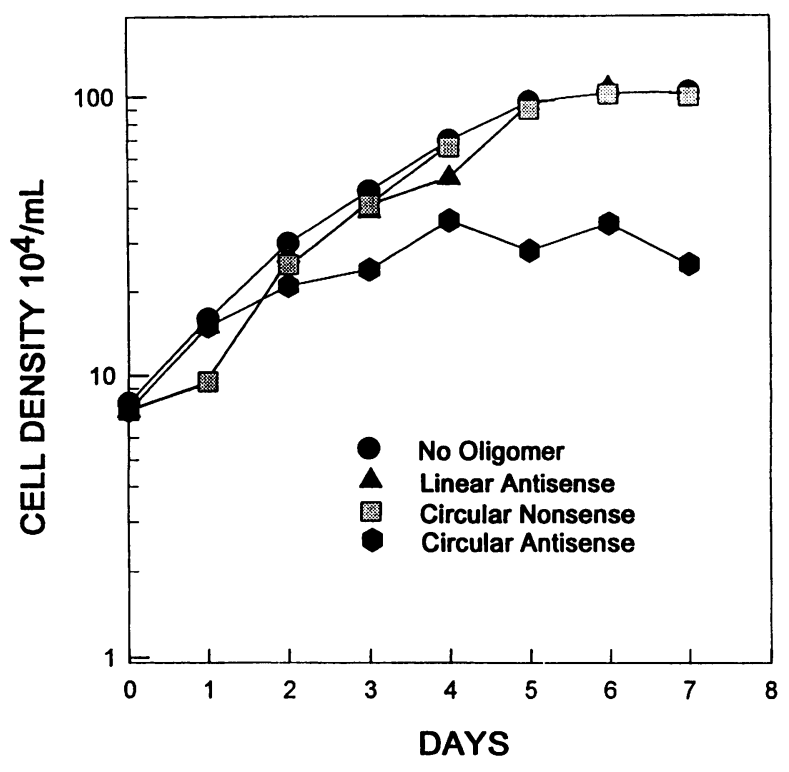

Fig. 2. Effect of oligonucleotides targeting the K562 bcr-abl mRNA 385 nucleotides 5' to the $b c r-a b l$ junction on cell density over 7 days. The sequence of the 34-nucleotide nonsense circle was 5'CCT TTC CGA CCC TTT CCT CTT TCC CCC CCT TTC T-3'. Oligonucleotide $(13 \mu \mathrm{M})$ was administered only on day 0 .

2 of $a b l$. The $b c r$ exon at the junction is either exon 3 (in the b3a2 type) or exon 2 (in the b2a2 type). To represent the b3a2 type we used $\mathrm{K} 562$ cells. To represent the b2a 2 type, we used BV173 cells.

\section{Studies with K562 Cells}

The ideal antisense target is the sequence at the $b c r$-abl junction because it is unique to the CML cell. However, in working with K562 cells, we were forced to choose as a target instead a polypurine sequence (all As and Gs) so that we could also use it as a complementary oligonucleotide to bring together the ends of the oligonucleotide to be circularized (26). (Conventional enzymatic methods using ligases do not efficiently close small circles.) Polypurine sequences as targets are advantageous because they form two types of bonds-not only Watson-Crick bonds but also Hoogsteen bonds. In combination, these two types of bonds facilitate bringing together the two ends as a linear antisense oligonucleotide, permitting their ligation by chemical means in order to form an uninterrupted circle.

We chose the long polypurine stretches closest to the b3a2 junction on either side, namely,

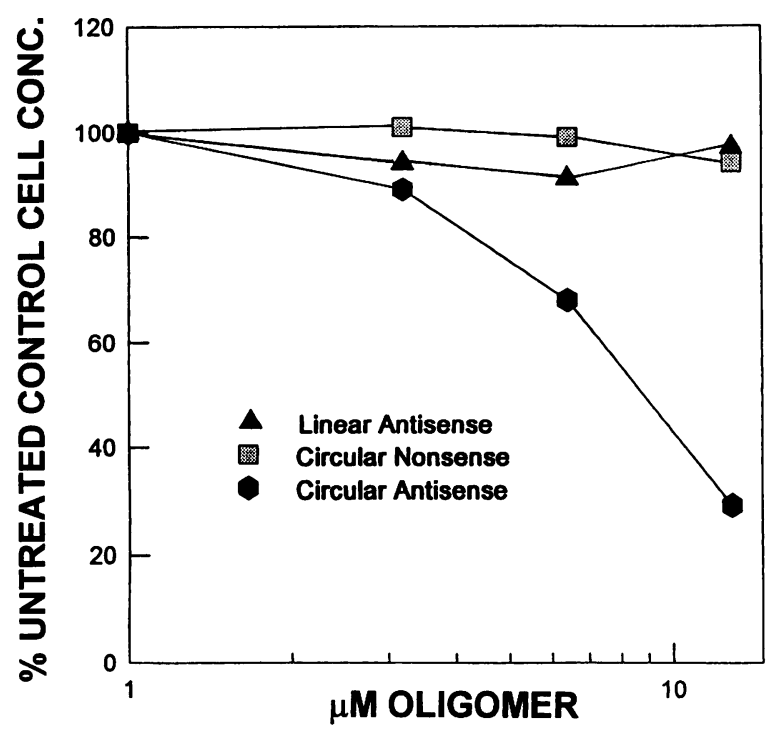

Fig. 3. Effect of various concentrations of oligonucleotide targeting the K562 bcr-abl mRNA 385 nucleotides $5^{\prime}$ to the $b c r-a b l$ junction on $\mathrm{K} 562$ cell density at 5 days.
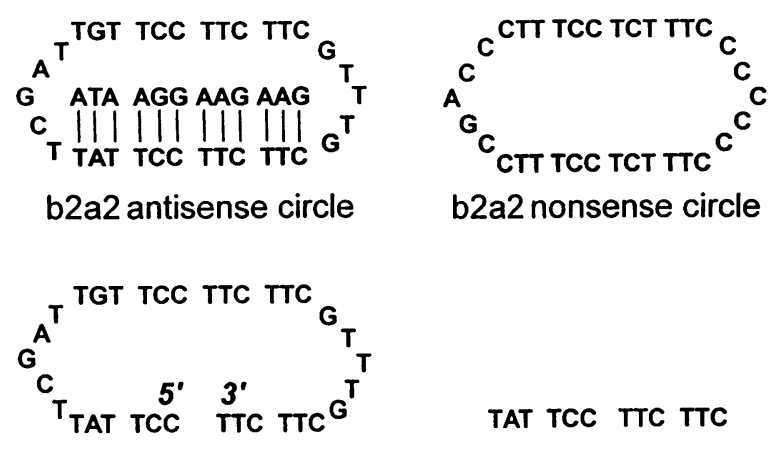

long linear antisense

TAT TCC TTC TTC

short linear antisense

Fig. 4. Structure of antisense circular oligonucleotide targeting the $b c r-a b l$ junction of BV173 cells and of control oligonucleotides.

385 nucleotides $5^{\prime}$ to the junction in the $b c r$ gene and 1735 nucleotides $3^{\prime}$ to the junction in the $a b l$ gene (Fig. 1). The oligomers were added to the culture only on the day the culture was initiated. Although the 36-nucleotide $a b l$-directed circle was inactive, the 34-nucleotide $b c r$-directed circle had activity. At $13 \mu \mathrm{M}$, the $b c r$ circle reduced the saturating cell number by $68 \%$ (note the log scale) (Fig. 2). The controls, including both an uncapped 12-nucleotide linear control containing just the Watson-Crick bonding region and a 34-nucleotide nonsense circle, had no effect.

The effects of the same agents at a variety of concentrations on day 5 are shown in Figure 3. The antisense circles had an antiproliferative ef- 


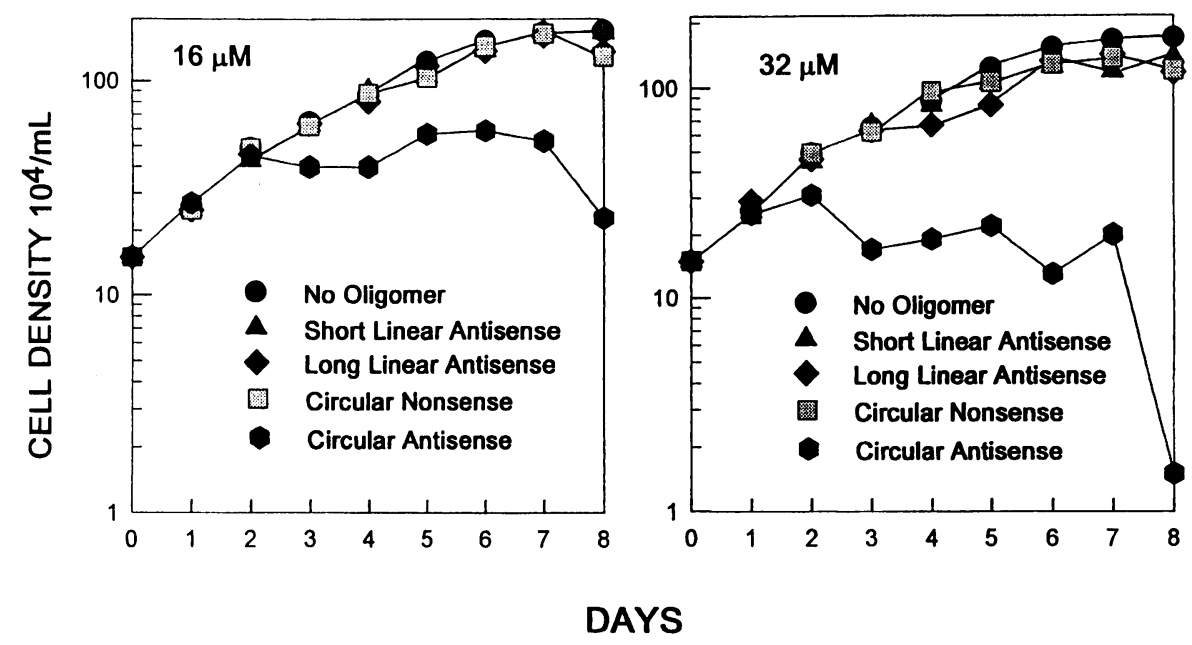

Fig. 5. Effect of oligonucleotides targeting the BV173 $b c r-a b l$ mRNA junction on cell density over 8 days. The oligonucleotide was added on day 0 at 16 $\mu \mathrm{M}$ (left) or $32 \mu \mathrm{M}$ (right). fect, even at $6 \mu \mathrm{M}$. The $50 \%$ inhibitory concentration $\left(\mathrm{IC}_{50}\right)$ was about $9 \mu \mathrm{M}$. Both the linear antisense and the circular nonsense controls were ineffective. At the same concentrations, neither agent had any effect on the proliferation of HL60 cells, a human leukemic cell line that lacks the $b c r-a b l$ mutation (data not shown).

\section{Studies with BVI73 Cells}

To determine whether the circles were equally effective against cells containing the other type of $b c r-a b l$ junction, b2a2, we used BV173 cells. Fortunately, the b2a2 junction itself is a polypurine sequence. Figure 4 shows the target sequence, the corresponding circular antisense agent, and a circle complementary to a target sequence with the same nucleotide composition but in scrambled sequence. We also used two linear controls, a so-called long linear antisense, which was the entire antisense circle sequence but without circularization, and a short linear antisense corresponding only to the WatsonCrick bonding region.

The results at 16 and $32 \mu \mathrm{M}$ are shown in Figure 5. At $16 \mu \mathrm{M}$, the cells arrested at a density $66 \%$ below that of the untreated control. At 32 $\mu \mathrm{M}$, cells arrested at nearly $90 \%$ below the untreated control. The $\mathrm{IC}_{50}$ was about $8 \mu \mathrm{M}$. Even at this concentration, the control sequences had little effect.

The effects of circular b2a2 antisense at various concentrations are shown in Figure 6 . Rather than day 5, as in the case of K562 cells, we chose day 7 because of the slower growth of the BV173 cell line. The antisense circle inhibits growth markedly, even at $3.5 \mu \mathrm{M}$. The control sequences (circular nonsense and short and long linear antisense) had virtually no effect. The circularization is clearly important because the same sequence prior to circularization (long linear sequence) had little effect.

\section{Stability of Circular Oligonucleotides}

To directly determine the stability of circles, we incubated circular and uncapped linear oligomers of the same length in $10 \%$ FBS at $37^{\circ} \mathrm{C}$ for 0-72 $\mathrm{hr}$ and analyzed the products on a sequencing gel. Uncapped linear agents formed a ladder

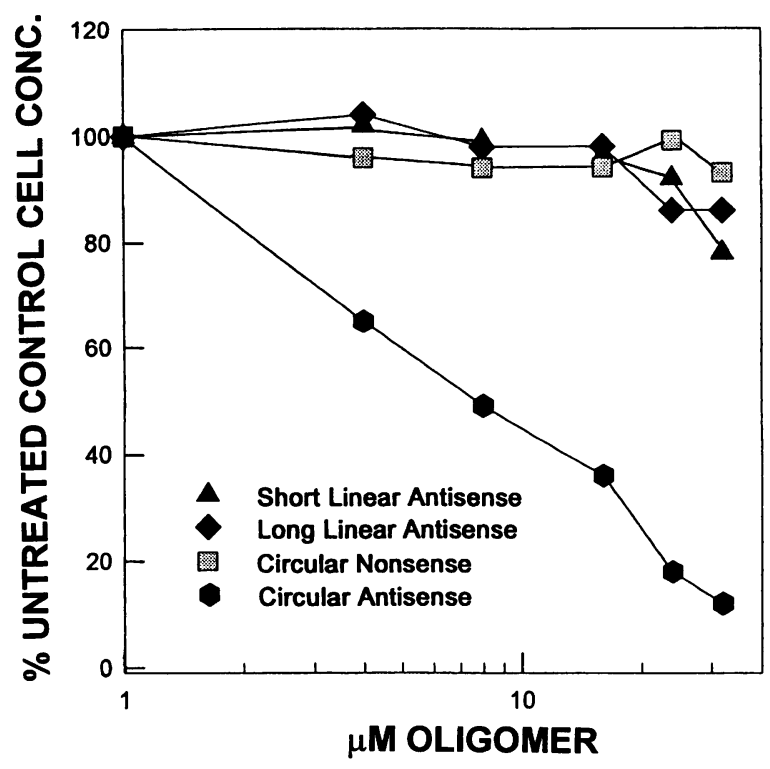

Fig. 6. Effect of various concentrations of oligonucleotide targeting the BV173 $b c r-a b l$ mRNA junction on BV173 cell density at 7 days. 


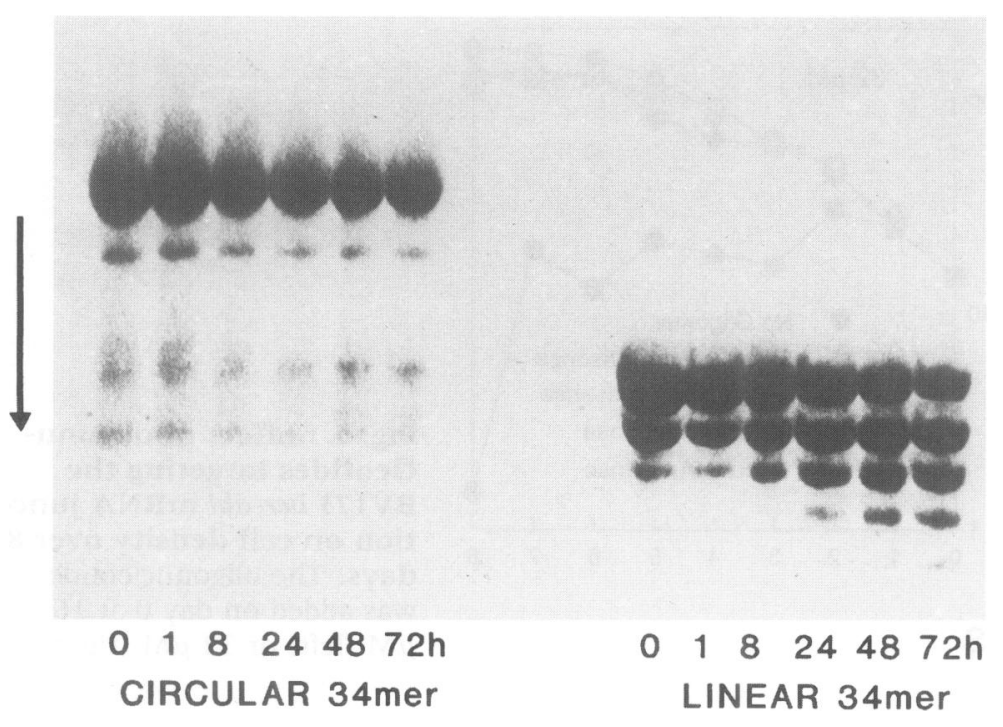

Fig. 7. Stability of deoxynucleotides. Oligomers were incubated in $10 \%$ fetal bovine serum at $37^{\circ} \mathrm{C}$ for $0-72 \mathrm{hr}$. At various times, the products were electrophoresed on a sequencing gel and stained with Stains-All. (Left) Circular 34mer 385 bcr circles, showing minimal degradation. (Right) Linear 34mer precursor before circularization, showing considerable degradation. of breakdown products (Fig. 7). No such progressive accumulation of breakdown products was seen in the case of the circular agents, indicating their greater stability.

\section{Effect on bcr-abl Protein}

To demonstrate that a given oligonucleotide is acting via an antisense mechanism, the most conclusive evidence is the demonstration that the protein product of the target gene has been reduced in amount. To determine whether our antisense circle reduced the amount of bcr-abl protein in treated cells, we used immunoblotting. BV173 cells were cultured with antisense or nonsense circle for 1, 2, or 3 days. The harvested cells were lysed and the lysate electrophoresed. The electropherogram was exposed to a specific anti-bcr-abl monoclonal antibody. The signal was captured as an image by chemiluminescence and quantitated by densitometry (Fig. 8).

This methodology showed that antisense circles specifically reduced bcr-abl protein content (Fig. 9). At $24 \mathrm{hr}$, antisense circle-treated cells
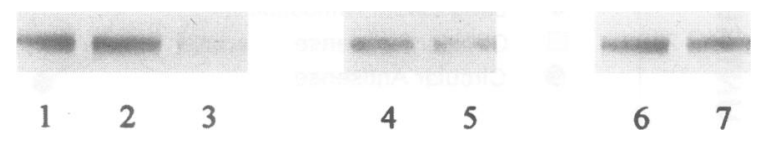

Fig. 8. Immunoblot of BV173 cell lysates using anti-abl monoclonal antibody. 1, untreated; 2 , nonsense circle-treated, $24 \mathrm{hr} ; 3$, antisense circletreated, $24 \mathrm{hr} ; 4$, nonsense circle-treated, $48 \mathrm{hr}$; 5 , antisense circle-treated, $48 \mathrm{hr} ; 6$, nonsense circletreated, $72 \mathrm{hr} ; 7$, antisense circle-treated, $72 \mathrm{hr}$. had $<10 \%$ of the bcr-abl protein content of nonsense circle-treated cells. This reduction, resulting from oligonucleotide addition only on day 0 , had largely disappeared by $72 \mathrm{hr}$, suggesting the need for repeated treatment as new cells are generated.

\section{Discussion}

In this report, we demonstrate that circular phosphodiester deoxynucleotides complementary to bcr-abl mRNA impair the accumulation of CML cells in culture. Sequence specificity was demonstrated by the absence of such an effect by a variety of control oligonucleotides. Activity was shown at modest concentrations and was dose-

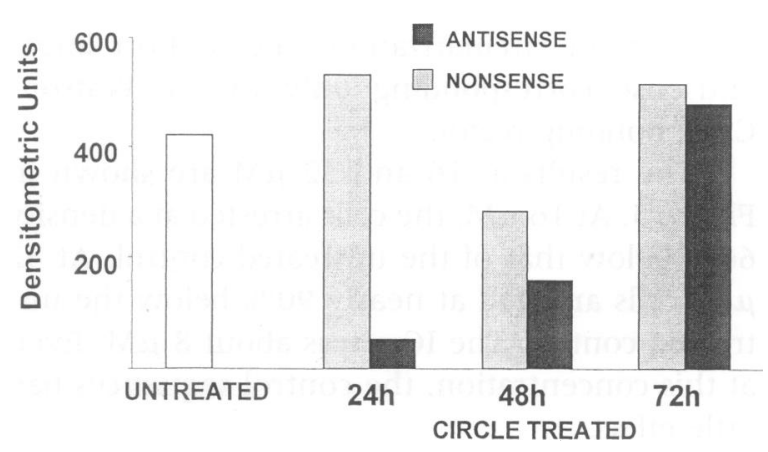

Fig. 9. Effect of circular oligonucleotides on bcr-abl content. Following BV173 culture with circular oligonucleotides at $12 \mu \mathrm{M}$ for $48 \mathrm{hr}$, cells were harvested and lysed, and membrane-free lysates assayed for bcr-abl protein by immunoblotting, as described in Materials and Methods. 
dependent. Stability in serum greatly exceeded that for linear oligonucleotides. Activity was demonstrated against cell lines representing $b c r-$ $a b l$ junctions of both $\mathrm{b} 3 \mathrm{~b} 2$ and $\mathrm{b} 2 \mathrm{a} 2$ types. Finally, an antisense mechanism was shown by a demonstration of reduction in the gene product.

Strictly speaking, it should be noted that the primary effect of these circles may not be inhibiting cell division. Our studies have shown that linear antisense agents were more effective in reducing the $b c r$-abl-induced impairment in apoptosis than in inhibiting DNA synthesis (6).

Circular oligonucleotides have a number of advantages over linear oligonucleotides as modulators of gene expression. These advantages include marked nuclease resistance, binding affinity, and sequence selectivity. The chemical basis for these properties has been described in detail (31). Circles also have some disadvantages, including the requirement for manual preparation, difficulty in closing the circle for certain oligonucleotide lengths, and the lack of a convenient method of labeling. The last-named disadvantage accounts for our lack of information on the kinetics of cellular uptake. Perhaps the most serious limitation is the limitation of target sequences to polypurine sequences. In the case of CML, this limitation prevented choosing the $b c r 3 / a b l 2$ junction as a target. Although an alternative target resulted in an equivalent $\mathrm{IC}_{50}$, a penalty might be the unintended targeting of some other mRNA that might share this sequence.

Nearly as important as the circular structure of these agents may be their phosphodiester structure. The substitution of other types of internucleotide linkages appears to contribute to the lack of sequence selectivity evident in the antisense oligonucleotide literature.

Circular oligonucleotides can be made, not only from DNA but also from RNA (28). An advantage of RNA circles over DNA circles for use as antisense molecules is their ability to bind a nucleotide in a target RNA molecule, not only by a Watson-Crick bond but also simultaneously by a Hoogsteen bond, thus forming a triplex structure (32). Because ribonuclease is so ubiquitous, the RNAse-resistant 2'-0-methyl derivative of RNA, which has similar DNA-binding properties, may be preferable to RNA itself (32).

This report demonstrates that one of the main obstacles to antisense therapeutics, the sensitivity of oligonucleotides to nucleases, can be addressed, not by modifying the phosphodiester structure but by circularization while preserving the phosphodiester structure. Although antisense therapy for leukemias may still face obstacles, chemical innovation is far from exhausted.

\section{Acknowledgments}

This work was supported by the AMA Education and Research Foundation, the American Cancer Society, the Elsa U. Pardee Foundation, the Leukemia Society of America, the Maxfield Foundation, the Milheim Foundation, and the Oliver S. and Jennie R. Donaldson Charitable Trust.

\section{References}

1. Rowley JD. (1973) A new consistent chromosomal abnormality in chronic myelogenous leukemia identified by quinacrine fluorescence and $\mathrm{Gi}$ emsa staining. Nature 243: 290-292.

2. Taj AS, Martiat P, Dhut S, et al. (1990) Inhibition of $\mathrm{P} 210^{b c r / a b l}$ expression in $\mathrm{K} 562$ cells by electroporation with an antisense oligonucleotide. Leuk. Lymphoma 3: 201-208.

3. Szczylik C, Skorski T, Nicolaides NC, et al. (1991) Selective inhibition of leukemia cell proliferation by $B C R-A B L$ antisense oligodeoxynucleotides. Science 253: 562-565.

4. Thomas M, Kosciolek B, Wang N, Rowley PT. (1994) Capping of $b c r-a b l$ antisense oligonucleotides enhances antiproliferative activity against chronic myeloid leukemia cell lines. Leuk. Res. 18: 401-408.

5. Shaw JP, Kent K, Bird J, Fishback J, Froehler B. (1991) Modified deoxyoligonucleotides stable to exonuclease degradation in serum. Nucl. Acids Res. 19: 747-750.

6. Rowley PT, Keng PC, Kosciolek BA. (1996) The effect of $b c r-a b l$ antisense oligonucleotide on DNA synthesis and apoptosis in K562 chronic myeloid leukemia cells. Leuk. Res. 20: 473-480.

7. Kirkland MA, O'Brien SG, McDonald C, Davidson RJ, Cross NCP, Goldman JM. (1993) BCR-ABL antisense purging in chronic myeloid leukaemia. Lancet 342: 614 .

8. Kabisch A, Perenyi L, Seay U, Lohmeyer J, Pralle H. (1994) Unmodified phosphodiester antisense oligodeoxynucleotides to the $B C R-A B L$ junction do not suppress Philadelphia-positive clonogenic cells. Acta Haematol. 92: 190-196.

9. O'Brien SG, Kirkland MA, Melo JV, et al. (1994) Antisense BCR-ABL oligomers cause non-specific inhibition of chronic myeloid leukemia cell lines. Leukemia 8: 2156-2162.

10. Smetsers TFCM, Skorski T, van de Locht LTF, et al. (1994) Antisense BCR-ABL oligonucleotides induce apoptosis in the Philadelphia chromosomepositive cell line BV173. Leukemia 8: 129-140. 
1 1. Maekawa T, Kimura S, Hirakawa K, Murakami A, Zon G, Abe T. (1995) Sequence specificity on the growth suppression and induction of apoptosis of chronic myeloid leukemia cells by $B C R-A B L$ antisense oligodeoxynucleoside phosphorothioates. Int. J. Cancer 62: 63-69.

12. Vaerman JL, Lammineur C, Moureau $P$, et al. (1995) BCR-ABL antisense oligodeoxyribonucleotides suppress the growth of leukemic and normal hematopoietic cells by a sequence-specific but nonantisense mechanism. Blood 86: 3891-3896.

13. Vaerman JL, Moureau P, Deldime F, et al. (1997) Antisense oligodeoxyribonucleotides suppress hematologic cell growth through stepwise release of deoxyribonucleotides. Blood 90: 331-339.

14. Smetsers TFCM, van de Locht LTF, Pennings AHM, Wessels HMC, de Witte TM, Mensink EJBM. (1995) Phosphorothioate BCR-ABL antisense oligonucleotides induce cell death, but fail to reduce cellular Bcr-Abl protein levels. Leukemia 9: $118-130$.

15. Bergan R, Connell Y, Fahmy B, Kyle E, Neckers L. (1994) Aptameric inhibition of p2 $10^{\text {bcr-abl }}$ tyrosine kinase autophosphorylation by oligodeoxynucleotides of defined sequence and backbone structure. Nucl. Acids Res. 22: 21 50-2154.

16. Bergan RC, Kyle E, Connell Y, Neckers L. (1995) Inhibition of protein-tyrosine kinase activity in intact cells by the aptameric action of oligodeoxynucleotides. Antisense Res. Dev. 5: 33-38.

17. Nichols GL. (1995) Antisense oligodeoxynucleotides as therapeutic agents for chronic myelogenous leukemia. Antisense Res. Dev. 5: 67-69.

18. Prakash G, Kool ET. (1991) Molecular recognition by circular oligonucleotides. Strong binding of single-stranded DNA and RNA. J. Chem. Soc. Chem. Commun. 1161-1162.

19. D'Souza DJ, Kool ET. (1994) Solvent, pH, and ionic effects on the binding of single-stranded DNA by circular oligodeoxynucleotides. Bioorg. Med. Chem. Lett. 4: 965-970.

20. Lozzio CB, Lozzio BB. (1975) Human chronic myelogenous leukemia cell-line with positive Philadelphia chromosome. Blood 45: 321-334.

21. Pegoraro L, Matera L, Ritz J, Levis A, Palumbo A, Biagini G. (1983) Establishment of a $\mathrm{Ph}^{1}$-positive human cell line (BV173). J. Natl. Cancer. Inst. 70: 447-453.

22. Beaucage SL, Caruthers MH. (1981) Deoxynucleoside phosphoramidites-a new class of key intermediates for deoxypolynucleotide synthesis. Tetrahedron Lett. 22: 1859-1862.

23. Horn T, Urdea MS. (1986) A chemical 5'-phosphorylation of oligodeoxyribonucleotides that can be monitored by trityl cation release. Tetrahedron Lett. 27: 4705-4708.

24. Sambrook J, Fritsch EF, Maniatis T. (1989) Molecular Cloning, 2nd Ed. Cold Spring Harbor Press, Cold Spring Harbor, NY, pp. 6.36-6.43.

25. Borer PN. (1975) Optical properties of nucleic acids, absorption, and circular dichroism spectra. In: Fasman GD (ed). Handbook of Biochemistry and Molecular Biology. CRC Press, Cleveland, p. 589.

26. Kool ET. (1991) Molecular recognition by circular oligonucleotides. Increasing the selectivity of DNA binding. J. Am. Chem. Soc. 113: 6265-6266.

27. Prakash G, Kool ET. (1992) Structural effects in the recognition of DNA by circular oligonucleotides. J. Am. Chem. Soc. 114: 3523-3527.

28. Wang S, Kool ET. (1994) Circular RNA oligonucleotides. Synthesis, nucleic acid binding properties, and a comparison with circular DNAs. Nucl. Acids Res. 22: 2326-2333.

29. Rubin E, Rumney S IV, Wang S, Kool ET. (1995) Convergent DNA synthesis: a non-enzymatic dimerization approach to circular oligodeoxynucleotides. Nucl. Acids Res. 23: 3547-3553.

30. Muller AJ, Young JC, Pendergast AM, et al. (1991) BCR first exon sequences specifically activate the $B C R / A B L$ tyrosine kinase oncogene of Philadelphia chromosome-positive human leukemias. Mol. Cell. Biol. 11: 1785-1792.

31. Kool ET. (1994) Circular oligonucleotides as potential modulators of gene expression. In: Akhtar $\mathrm{S}$ (ed). Delivery Systems for Antisense Oligonucleotide Therapeutics. CRC Press, Boca Raton, FL, pp. 123149.

32. Wang S, Kool ET. (1995) Relative stabilities of triple helices composed of combinations of DNA, RNA and 2'-0-methyl-RNA backbones: chimeric circular oligonucleotides as probes. $\mathrm{Nucl}$. Acids Res. 23: 1157-1164. 